\title{
Przegląd metod oceny funkcjonalnej analizujących motorykę małą i duzą u chorych z rdzeniowym zanikiem mięśni
}

\section{A review of functional assessment scales analyzing gross and fine motor skills in patients with spinal muscular atrophy}

\author{
Aleksandra Włodarczyk iD, Ewa Gajewska² iD \\ ${ }^{1}$ Wydział Nauk o Zdrowiu, Uniwersytet Medyczny im. Karola Marcinkowskiego, doktorantka Szkoły Doktorskiej \\ Faculty of Health Sciences, Karol Marcinkowski University of Medical Sciences, a PhD student \\ ${ }^{2}$ Katedra i Klinika Neurologii Wieku Rozwojowego Uniwersytet Medyczny im. Karola Marcinkowskiego w Poznaniu \\ Department of Developmental Neurology Karol Marcinkowski University of Medical Sciences in Poznań
}

DOI:10.20966/chn.2019.56.437

\section{STRESZCZENIE}

Rdzeniowy zanik mięśni jest postępującą chorobą genetyczną, której częstość występowania szacuje się na 1:11 000 żywych urodzeń. Charakteryzuje się degeneracją motoneuronów alfa czego efektem jest postępujące osłabienie siły mięśniowej, arefleksja w zakresie odruchów ścięgnistych, a także spowolnienie rozwoju motorycznego i zaburzenia oddychania. W przypadku pacjentów z typem 1 najpopularniejszymi skalami oceniającymi rozwój motoryczny jest CHOP-INTEND i Hammersmith Infant Neurological Examination, które bazują na osiągniętych przez dziecko kamieniach milowych. Wśród narzędzi skierowanych dla pacjentów z typem 2 i 3 największe klinicznie znaczenie mają skala Hammersmith i Motor Function Measure oceniające określone funkcje motoryczne oraz 6 minutowy test chodu badający zdolność chodzenia i zmęczenie. Narzędziem skierowanym bezpośrednio do oceny motoryki małej jest skala Revised Upper Limb Module. Ze względu na ciąglą konieczność rehabilitacji i świadomości stopnia progresji choroby konieczne jest stosowanie przez fizjoterapeutów zwalidowanych narzędzi oceniających motorykę małą i dużą u pacjentów z rdzeniowym zanikiem mięśni.

Słowa kluczowe: rdzeniowy zanik mięśni, skale funkcjonalne, skala Hammersmith, 6-minutowy test chodu, Nusinersen
ABSTRACT

Spinal muscular atrophy is a progressive genetic disease with frequency estimated at 1:11 000 live births. It is caused by degeneration of alphamotoneurons resulting in progressive weakening of muscles strength, areflexia of tendon reflexes as well as slowdown in motor skills and respiratory disorders. For patients with type 1 the most popular scales assessing functional motor skills are CHOP-INTEND and Hammersmith Infant Neurological Examination, which are based on milestones achieved by a child. Among the methods for patients with type 2 and 3 , the Hammersmith and Motor Function Measure scales assessing specific motor functions are the most clinically important. A 6-minute walk test which checks gait ability and fatigue is equally significant in this group of patients. Revised Upper Limb Module is a tool aimed directly at the assessment of small motor ability. Due to constant need for rehabilitation and awareness of disease progress, it is necessary for physiotherapists to use validated methods assessing fine and gross motor skills in patients with spinal muscular atrophy.

Keywords: spinal muscular atrophy, functional assessment scales, Hammersmith functional motor scale, 6-minute walk test, Nusinersen

\section{CZYM JEST SMA?}

Rdzeniowy zanik mięśni (ang. spinal muscular atrophy SMA) jest postępującą chorobą genetyczną, dziedziczoną w sposób autosomalny recesywny. Charakteryzuje się degeneracją motoneuronów alfa - komórek rogów przednich rdzenia kręgowego, co objawia się postępującym osłabieniem siły mięśniowej oraz arefleksją w zakresie odruchów ścięgnistych. Wtórnie prowadzi to do spowolnionego rozwoju motorycznego, zaburzeń oddychania i tworzenia przykurczów stawowych [1-3]. Częstość występowania szacuje się na około 1:11 000 żywych urodzeń, natomiast nosicielstwo występuje średnio u 1 na 54 osób [4, 5]. Przebieg i stopień zaawansowania choroby jest różny w zależności od typu SMA. Wyróżniamy cztery główne typy rdzeniowego zaniku mięśni, które różnią się wzglę- dem siebie nasileniem objawów, osiąganym przez dziecko stopniem rozwoju motorycznego oraz okresem przeżywalności (tab. I) [2, 4].

SMA spowodowane jest homozygotyczną delecją lub mutacją w obrębie genu SMN1 odpowiedzialnego za produkcję białka przeżywalności motoneuronów - SMN. W ludzkim organizmie występuje paralogiczny gen SMN2, który również koduje białko SMN, jednakże z powodu wadliwego splicingu w $90 \%$ powstałe białko jest skrócone i nie spełnia w pełni swojej funkcji [1]. Im więcej kopii genu SMN2 posiada dziecko, tym łagodniejsza jest postać SMA [6]. Od 1 stycznia 2019 roku w Polsce wprowadzono leczenie przy wykorzystaniu nusinersenu (spinraza) pierwszego leku leczącego przyczynę SMA. Lek ten jest oligonukleotydem modyfikującym wadliwy splicing pre- 
Tab. I. Typy SMA

Tab. I. Types of SMA

\begin{tabular}{|c|c|c|c|}
\hline $\begin{array}{c}\text { Typ SMA } \\
\text { Type of SMA }\end{array}$ & $\begin{array}{l}\text { Charakterystyka } \\
\text { Characteristic }\end{array}$ & $\begin{array}{c}\text { Początek } \\
\text { objawów } \\
\text { Onset of } \\
\text { symptoms }\end{array}$ & $\begin{array}{c}\text { Okres } \\
\text { przeżycia } \\
\text { Survival } \\
\text { period }\end{array}$ \\
\hline I & $\begin{array}{l}\text { Nie siedzi } \\
\text { samodzielnie, } \\
\text { ogólna wiotkość, } \\
\text { słaby kaszel i } \\
\text { kichanie }\end{array}$ & $<6 \mathrm{~m} \cdot \dot{z}$ & $<2$ lata \\
\hline II & $\begin{array}{l}\text { Samodzielnie } \\
\text { siedzi, ale nie } \\
\text { chodzi, opóźniony } \\
\text { rozwój ruchowy, } \\
\text { skoliozy, } \\
\text { przykurcze } \\
\text { stawowe, } \\
\text { osłabienie mięśni } \\
\text { oddechowych }\end{array}$ & 6-18 m.ż & $\begin{array}{l}<\text { populacja } \\
\text { ogólna }\end{array}$ \\
\hline III & $\begin{array}{l}\text { Chodzi } \\
\text { samodzielnie, } \\
\text { osłabienie } \\
\text { mięśni, } \\
\text { przykurcze, } \\
\text { pojawiające } \\
\text { się z czasem } \\
\text { utrata zdolności } \\
\text { chodzenia }\end{array}$ & $>18 \mathrm{~m} \cdot \dot{z}$ & $\begin{array}{l}=\text { populacji } \\
\text { ogólnej }\end{array}$ \\
\hline IV & $\begin{array}{l}\text { Rozwój } \\
\text { motoryczny } \\
\text { prawidłowy, } \\
\text { osłabienie siły } \\
\text { mięśniowej }\end{array}$ & $\begin{array}{l}>30 \text { roku } \\
\text { życia }\end{array}$ & $\begin{array}{l}\text { = populacji } \\
\text { ogólnej }\end{array}$ \\
\hline
\end{tabular}

-mRNA genu SMN2 $[1,4,7,8]$. Ze względu na ciągłą konieczność rehabilitacji oraz świadomości stopnia progresji choroby konieczne jest używanie przez fizjoterapeutów zwalidowanych narzędzi diagnostycznych oceniających poziom funkcjonalny dziecka z SMA. Skale te zalecane są przez Narodowy Fundusz Zdrowia w ramach tzw. programu terapeutycznego u pacjentów przyjmujących nusinersen w celu monitorowania zmian w zakresie ich rozwoju motorycznego [9].

Celem pracy jest przegląd narzędzi oceniających motorykę małą i dużą w tej grupie pacjentów.

\section{METODY OCENIAJĄCE MOTORYKĘ DUŻĄ I MAŁA U PACJENTÓW Z SMA TYPU 1}

Skala CHOP-INTEND (Children's Hospital of Philadelphia Infant Test of Neuromuscular Disorders) określa stopień zaburzeń nerwowo-mięśniowych u dzieci z SMA typu 1. Zwraca uwagę na sposób wykonywania przez dziecko 16 pozycji skupiając się na analizie ruchów spontanicznych lub celowych w zależności od stanu poznawczego dziecka. Jej elementy oceniają również motorykę małą. Maksymalna liczba punktów w skali to 64 - minimalna ocena dla każdego podpunktu to 0 , natomiast za prawidłowe wykonanie zadania można uzyskać najwięcej 4 punkty. Dziecko musi być badane najlepiej rano, kiedy jest ożywione. Dozwolone są trzy próby wykonywania danej czynności $[2,10]$.

Skala HINE (Hammersmith Infant Neurological Examination) jest kolejnym narzędziem bazującym na osiągniętych przez dziecko kamieniach milowych. Składa się z dwóch części: pierwszej oceniającej badanie neurologiczne oraz drugiej - badającej 8 pozycji bazujących na rozwoju motorycznym dziecka. Ocenie podlega m.in. kontrola głowy, siad, świadomy chwyt, obroty, czworakowanie czy też chód. Punkty wahają się w zakresie od 0 do 26 z podpunktami ocenianymi w granicy 0-4 (poszczególne punkty odpowiadają rozwojowi fizjologicznemu dziecka) $[2,5]$.

\section{METODY OCENIAJĄCE MOTORYKĘ DUŻĄ I MAtĄ U PACJENTÓW Z SMA TYPU 2 I 3}

Do oceny mobilności u pacjentów z typem 2 i 3 wykorzystywana jest między innymi skala Hammersmith (HMF$\mathrm{ME}$ ). Jest ona pierwszym, specyficznym narzędziem oceniającym funkcje motoryczne w tej grupie pacjentów. Zbudowana jest z 20 podstawowych pytań ułożonych w porządkowej kolejności, oceniających poszczególne funkcje motoryki dużej w zakresie od 0 do 2, gdzie 0 określa brak wykonania czynności, 1 wykonanie zadania z kompensacją, natomiast 2 - prawidłowe wykonanie zadania. Oceniane są takie umiejętności jak siad, obroty, czworakowanie, podpór na przedramionach i łokciach czy unoszenie głowy. Ważne jest, aby test wykonywany był o tej samej porze, przez tego samego terapeutę. Podczas trwania oceny pacjent powinien mieć na sobie minimalną ilość odzieży zapewniającą komfort: najlepiej koszulkę i spodenki. Nie należy stosować zaopatrzenia ortopedycznego. Każde zadanie można wykonać dopiero po ułożeniu pacjenta we właściwej pozycji wyjściowej. Dziecko ma możliwość trzykrotnego powtórzenia danej czynności, a terapeuta ocenia najlepiej wykonaną próbę. Skala ta rozbudowana jest również o moduł dodatkowy zawierający 13 pytań pochodzących ze skali GMFM oceniających bardziej zaawansowane umiejętności skierowane dla pacjentów z SMA typu 3. Maksymalna liczba punktów do uzyskania to 66 [11].

W trakcie badań zauważono jednak, że skala HMFME nie sprawdza się w pełni u dzieci mających mniej niż 30 miesięcy, dlatego stworzono Zmodyfikowaną Skalę Hammersmith, która nieznacznie różni się od pierwotnej (tab. II). Założenia i warunki przeprowadzenia testów są podobne, jednakże 20 ocenianych czynności ustalonych jest w innej kolejności, w taki sposób, aby nie narażać dziecka na zbyt duże zmęczenie i stres. Ponadto możliwe jest korzystanie $z$ dodatkowych bodźców środowiskowych takich jak np. zabawki, celem zmniejszenia zakłóceń środowiska i zwiększenia efektywności wykonywanych pomiarów. Uproszczono również opis zadawanych poleceń. [12].

Skala MFM (ang. Motor Function Measure) jest kolejnym, zwalidowanym narzędziem służącym do liczbowego pomiaru zdolności motorycznych pacjentów z SMA typu 2 
Tab. II. Porównanie oryginalnej i zmodyfikowanej skali Hammersmith

Tab. II. The comparison of original and modified Hammersmith functional motor scale

\begin{tabular}{|c|c|c|}
\hline & $\begin{array}{l}\text { Oryginalna skala Hammersmith } \\
\text { Original Hammersmith functional motor scale }\end{array}$ & $\begin{array}{l}\text { Zmodyfikowana skala Hammersmith } \\
\text { Modified Hammersmith functional motor scale }\end{array}$ \\
\hline 1 & Siedzi na krześle bez podparcia rąk & Siedzi na podeście/krześle bez podparcia rąk \\
\hline 2 & Długie siedzenie. Bez podparcia rąk & Długie siedzenie. Bez podparcia rąk \\
\hline 3 & Przewracanie na bok z leżenia na wznak & $\begin{array}{l}\text { Uniesienie jednej ręki na wysokość uszu podczas } \\
\text { siedzenia }\end{array}$ \\
\hline 4 & Dotykanie jedną ręką glowy podczas siedzenia & $\begin{array}{l}\text { Unoszenie dwóch rąk na wysokość uszu podczas } \\
\text { siedzenia }\end{array}$ \\
\hline 5 & Dotykanie obiema rękami głowy podczas siedzenia & Zmiana pozycji z siedzącej na leżącą \\
\hline 6 & Przewracanie się z brzucha na wznak przez prawe ramię & Podnoszenie głowy z nad podłoża z pozycji na wznak \\
\hline 7 & Przewracanie się z brzucha na wznak przez lewe ramię & Przewracanie na bok z leżenia na wznak \\
\hline 8 & $\begin{array}{l}\text { Przewracanie się na brzuch z leżenia na wznak przez } \\
\text { prawe ramię }\end{array}$ & Przewracanie się z brzucha na wznak przez prawe ramię \\
\hline 9 & $\begin{array}{l}\text { Przewracanie się na brzuch z leżenia na wznak przez lewe } \\
\text { ramię }\end{array}$ & Przewracanie się z brzucha na wznak przez lewe ramię \\
\hline 10 & Zmiana pozycji z siedzącej na leżącą & $\begin{array}{l}10 \text { Przewracanie się na brzuch z leżenia na wznak przez } \\
\text { prawe ramię }\end{array}$ \\
\hline 11 & Podpieranie się na przedramionach & $\begin{array}{l}11 \text { Przewracanie się na brzuch z leżenia na wznak przez lewe } \\
\text { ramię }\end{array}$ \\
\hline 12 & Podnoszenie głowy leżąc na brzuchu & 12 Podnoszenie głowy leżąc na brzuchu \\
\hline 13 & $\begin{array}{l}\text { Klękanie z podparciem rękami (pozycja czworacza) - } \\
\text { głowa uniesiona }\end{array}$ & 13 Podpieranie się na przedramionach \\
\hline 14 & Podpieranie się na wyprostowanych ramionach & 14 Podpieranie się na wyprostowanych ramionach \\
\hline 15 & Zmiana pozycji z leżącej na siedzącą & 15 Klękanie z podparciem rękami (pozycja czworacza) \\
\hline 16 & Czworakowanie & 16 Czworakowanie na rękach i kolanach \\
\hline 17 & Podnoszenie głowy z pozycji na wznak & 17 Zmiana pozycji z leżącej na siedzącą \\
\hline 18 & Stanie z podparciem jednej dłoni & Stanie z podparciem jednej dłoni \\
\hline 19 & Stanie bez podparcia przez 3s. & 19 Stanie bez podparcia przez 3s. \\
\hline 20 & Przejście czterech kroków bez podparcia & 20 Przejście czterech kroków bez podparcia \\
\hline
\end{tabular}

i 3. Wyjściowo składa się z 32 zadań (MFM-32), jednakże z powodu trudności z wykonaniem części poleceń przez młodszą grupę pacjentów (nieodpowiednie zadania dla ich rozwoju psychoruchowego) stworzono dodatkowo skróconą wersję (MFM-20) dla dzieci poniżej 6 roku życia. Zadania ruchowe oceniane są na trzech obszarach: D1 - stanie i przenoszenie, D2 - funkcje motoryczne w obszarze osiowym i proksymalnym oraz D3 - funkcje motoryczne w obszarze dystalnym. Badanie należy przeprowadzić bez żadnej pomocy ze strony fizjoterapeuty, jednakże zalecane jest zachęcanie i stymulowanie pacjenta do podjęcia próby. Pacjent może wykonać dwa powtórzenia danej czynności z równoczesnym ocenieniem przez fizjoterapeutę najlepszej z prób. Ważne jest zachowanie kolejności zadań oraz wykorzystywanie zawsze tego samego sprzętu (wyszczególnionego w podręczniku testu). Dziecko powinno mieć analogiczny strój jak w HMFME, nie może również korzystać z żadnego zaopatrzenia ortopedycznego. W MFM sprawdzane są zdolności zarówno z zakresu motoryki małej jak i dużej tj. unoszenie głowy, zmiana pozycji z leżącej na siedzącą, przewracanie się z placów na brzuch oraz trzymanie monet, darcie kartki papieru czy rysowanie pętli. Każde z zadań oceniane jest od 0 do 3 punktów, gdzie 0 oznacza brak wykonanej czynności, 1 jej inicjowanie, 2 - wykonywanie ruchu w pełnym lub niepełnym zakresie z kompensacją, natomiast 3 - prawidłowe zaprezentowanie ocenianego polecenia. Terapeuta może opisać słownie lub zademonstrować dziecku oceniane zadanie. Uzyskany wynik jest procentową wartością maksymalnej oceny danego obszaru tj. suma punktów uzyskanych przez pacjenta w zadaniach z danej grupy, podzielona przez maksymalny wynik dla obszaru i pomnożona przez 100 [13].

6-minutowy test chodu (6MWT - ang. 6 Minute Walk Test) jest jedynym narzędziem przeznaczonym tylko dla chodzących pacjentów z SMA. Służy do oceny zdolności chodzenia i zmęczenia u dzieci z typem 3 rdzeniowego zaniku mięśni. Pacjent ma za zadanie chodzić przez 6 minut po 25-metrowym dystansie tak szybko jak to tylko możliwe. Dystans pokonany w każdej minucie jest rejestrowany przez doświadczonego fizjoterapeutę. Po przebytym teście 
dodatkowo wyznaczana jest ocena zmęczenia polegająca na odjęciu odległości przebytej w szóstej minucie od odległości przebytej w pierwszej minucie. Pomiary wyrażone są w procentach, a wartość dodatnia oznacza zmęczenie pacjenta [14].

Skala RULM (ang. Revised Upper Limb Module) służy do oceny funkcji motoryki małej w grupie pacjentów SMA typu 2 i 3. Jej użycie ma na celu monitorowanie zmian w sprawności kończyny górnej zachodzących z upływem czasu, uwzględniając w badaniu m.in.: siłę mięśniową, przykurcze czy ograniczenia w obrębie postawy. Pacjent badany jest przy użyciu konkretnego zestawu badawczego (składającego się m.in. z żetonów, włącznika światła, metalowych odważników o różnej masie czy plastikowego pojemnika z przykrywką). Dziecko powinno być oceniane zawsze przez tego samego terapeutę, mniej więcej o tej samej porze dnia, z wykorzystaniem zawsze tej samej, na ogół dominującej strony. Ocenie podlega 20 ułożonych kolejno czynności, które pacjent może powtórzyć trzykrotnie. Badanie wykonywane jest w pozycji siedzącej (w razie potrzeby z użyciem wózka inwalidzkiego), a każde zadanie rozpoczynane jest od określonej pozycji wyjściowej. Aktywności ocenianie są od 0 do 2, gdzie 0 oznacza brak wykonanej czynności, 1 - wykonanie z kompensacją, a 2 prawidłowe wykonanie zadania. Maksymalna liczba punktów do uzyskania to 40 [15].

Wszystkie powyższe testy przeznaczone zostały dla określonego typu SMA jednak w dobie zmian w rozwoju funkcjonalnym wynikających z podawania leku powinny być stosowane nie $\mathrm{z}$ uwzględnieniem danego typu a możliwości motorycznych pacjentów.

\section{PIŚMIENNICTWO}

[1] Darras B.T., Chiriboga C.A., lannaccone S.T., et al.: Nusinersen in lateronset spinal muscular atrophy: Long-term results from the phase $1 / 2$ studies. Neurology 2019; 92: 2492-2506.

[2] Gierlak-Wójcicka Z., Burlewicz M., Potulska-Chromik A., et al.: Przegląd metod oceny funkcjonalnej u niesiedzących pacjentów z rdzeniowym zanikiem mięśni (SMA). Neurol Dziec 2018; 54: 11-17.

[3] Kroczka S., Steczkowska M., Kaciński M.: Neurophysiological studies on muscles and peripheral nerves in children with moleculary diagnosed spinal muscular atrophy, Child Neurology 2009; 35: 27-34.

[4] Finkel R.S., Mercuri E., Darras B.T., et al.: Nusinersen versus Sham Control in Infantile-Onset Spinal Muscular Atrophy. N Engl J Med. 2017; 2: 377(18): 1723-1732.

[5] Mandell J.R., Al-Zaidy S., Shell R., et al.: Single-Dose Gene-Replacement Therapy for Spinal Muscular Atrophy. N Engl J Med. 2017; 2: 377(18): 1713-1722.

[6] Calucho M., Bernal S., March F., et al.: Correlation between SMA type and SMN2 copy number revised: An analysis of 625 unrelated Spanish patients and a compilation of 2834 cases. Neuromuscul Disord 2018; 28: 208-215.

[7] Faravelli I., Meneri M., Saccomanno D., et al.: Nusinersen treatment and cerebrospinal fluid neurofilaments: An explorative study on Spinal Muscular Atrophy type 3 patients. J Cell Mol Med. 2020.

[8] Goodkey K., Aslesh T., Maruyama R., et al.: Nusinersen in the Treatment of Spinal Muscular Atrophy. Methods Mol Biol. 2018; 1828: 69-76.

[9] Jędrzejowska M., Kostera-Pruszczyk A.: Rdzeniowy zanik mięśni - nowe terapie, nowe wyzwania. Neurol Dziec 2016; 25, 51: 11-17.

[10] Aragon-Gawińska K., Daron A., Ulinici A., et al.: Sitting in patients with spinal muscular atrophy type 1 treated with nusinersen. Dev Med Child Neurol. 2020; 62: 310-314.

[11] Ramsey D., Scoto M., Mayhew A., et al.: Revised Hammersmith Scale for spinal muscular atrophy: a SMA specific clinical outcome assessment tool; PLoS One; 2017; 12: 2.

[12] Krosschell K.J., Maczulski J.A., Crawford T.0., et al.: A modified Hammersmith functional motor scale for use in multi- center research on spinal muscular atrophy. Neuromuscul Disord. 2006; 16: 417-426.

[13] Bérard C., Payan C., Hodgkinson l., et al.: MFM Collaborative Study Group. A motor function measure for neuromuscular diseases. Construction and validation study. Neuromuscul Disord 2005; 15: 463-470.

[14] Montes J., Dunaway Young S., Mazzone E.S., et al.: Nusinersen improves walking distance and reduces fatique in later-onset spinal muscular atrophy. Muscle Nerve 2019; 60: 409-414.

[15] Mazzone E.S., Mayhew A., Montes J., et al.: Revised upper limb module for spinal muscular atrophy: Development of a new module. Muscle Nerve 2016; 55: 869-874. 